Research Articles

\title{
Sedimentology and Depositional Environment of D2 Sand in Part of Greater Ughelli Depobelt, Onshore Niger Delta, Nigeria
}

\author{
Prince Suka Momta, Jonathan O. Omoboh and Minapuye I. Odigi \\ Department of Geology, University of Port Harcourt, Nigeria
}

Article history

Received: 31-01-2015

Revised: 14-04-2015

Accepted: 15-06-2015

Corresponding Author: Prince Suka Momta

Department of Geology,

University of Port Harcourt,

Nigeria

Email: princemomta@yahoo.com

\begin{abstract}
The sedimentology and depositional environment of D2 sand in part of the Greater Ughelli depobelt have been studied using well logs and core data. Three wells were correlated to establish the lateral continuity of the D2 sand across the field and standard gamma ray log trends was used to infer depositional environments. Cored section of well $\mathrm{B}$ was described to identify lithology and delineate depositional environments based on facies types and sedimentary structures. Petrophysical characteristics of the reservoir of interest was generated using Archie Equation for water saturation, Timur formula for permeability computation and porosity values was determined quantitatively from density log. The results of the analysis showed that the D2 sand cut across the field. The reservoir displayed a funnel shaped coarsening upward gamma ray motif typical of a deltaic and progradational depositional profile. Four facies associations indicating four subenvironments within the deltaic front have been identified from the cored interval (3444.5 to $3458.5 \mathrm{~m}$ ) of the D2 reservoir. Each facies unit was identified based on lithology and sedimentary structures of the core sample, textural characteristics and gamma ray log trend. The four lithofacies associations: A, B, C and D include muddy heterolithic sandstone, trough cross stratified sandstone, sandy/silty mudstone and crossbedded sandstones. These facies correspond to Lower Shoreface, Upper Shoreface, Tidal Flat and Channel sand respectively. Petrophysical analysis revealed the trend of reservoir quality within the facies. Porosity range from 0.79 to $10.32 \%$, whereas permeability from 0.25 to $8.8 \mathrm{mD}$. Water saturation is high (0.8) within the poor quality facies and 0.3 in the highest porosity and permeability interval. Good porosity and permeability occurred within the channel and upper shoreface facies, whereas the tidal flat and lower shoreface have poor porosity and permeability values. The Shoreface facies has the best reservoir properties $(10.32 \%$ porosity and $8.8 \mathrm{mD}$ permeability) due to lack of shale intercalations and good sorting resulting from the sediments being properly reworked by wave action. The Channel facies (D) deposited by high energy current also has good reservoir properties, especially towards its base. The Tidal Flat facies has the lowest reservoir quality due to high proportion of shale/Clay that creates permeability barriers and occurred between the Upper shoreface facies and Channel sand facies. Sedimentology and depositional environments of facies have significant control on the quality of sand bodies.
\end{abstract}

Keywords: Sedimentology, Upper Shoreface, Agbada Formation, Reservoir, Depobelt 


\section{Introduction}

\section{Research Background}

Environments of deposition of sedimentary rocks play significant role in controlling the geometries of geobodies, architecture, grain-to-grain arrangement of framework particles and the accumulation of fluids within the pores of the rock (Keele and Evans, 2008; Arochukwu, 2014; Fitch et al., 2014). Each environment where sediments are deposited is unique in its physical and chemical characteristics and represents the processes that formed the environment (Snedden and Bergman, 1999; Slatt, 2006). Modern and ancient sedimentary environments can be identified from subsurface cores and outcrops using distinct sedimentary structures (Slatt, 2006). Cores of sedimentary rocks are important and diagnostic in environmental reconstruction because it contains rock in situ parameters. Environments of deposition of Niger Delta formations have been studied using cores, ditch-cuttings and wireline logs (Amajor and Agbaire, 1989; Reijers, 2011).

This study involves the integration of both well logs and core data to reconstruct the sedimentology and depositional history of the D2 sand occurring within the Agbada stratigraphic unit. The Agbada Formation occurs between both the Akata marine clay and the continental regressive offlap of the Benin Formation (Ejedawe, 1981; Amajor and Agbaire, 1989; Reijers, 2011; Momta and Odigi, 2014). These three formations are the key stratigraphic units that make up the Niger Delta sedimentary fills. The Agbada Formation comprising of alternation of sandstone and shale in almost equal proportion forms the major hydrocarbon habitat (Magbagbeoloa and Willis, 2007; Reijers, 2011). The objectives of this study involves the reconstruction of the sedimentology and depositional environments of the D2 sand; to construct a representative facies models of the environments and compare the petrophysical characteristics of the various environments. The outcome of the study will serve as analogue for the identification of similar genetic facies, its petrophysical characteristics and the understanding of flow behaviour. Detailed study of the sedimentology and depositional setting of the sand bodies will be vital to further exploratory work and the exploitation of huge hydrocarbon resources in the Agbada Formation.

\section{Geologic Setting of the Niger Delta}

The tectonic history and the evolution of the Niger Delta sedimentary basin have been reported by many workers (Whiteman, 1982; Doust and Omatsola, 1990; Reijers, 2011). The Niger Delta basin is situated in the Gulf of Guinea on the coast of West African continental margin (Fig. 1).
The basin evolved following the separation of African and South American plates during the Early Cretaceous times. This was followed by the opening of the South Atlantic Ocean and several episodes of transgressions and regressions accounted for the sedimentary fills in both the Cretaceous and Tertiary Southern Nigerian sedimentary basins. The sequence of evolution of the delta started with the continentcontinent break up, filling and the folding Santonian event of the Benue Trough, the development and filling of the Anambra basin and the subsequent development of the Niger Delta resulting from the subsidence that occurred down dip of the Anambra Basin. The delta covers an area extent of about $100,000 \mathrm{~km}^{2}$ and represents the regressive phase of the third cycle of deposition in the southern Nigeria sedimentary basins, which began during the Paleocene and has continued to the present day (Bruso et al., 2004; Reijers, 2011).

Stratigraphically, the subsurface sedimentary sequences are made up of basically three lithofacies of distinct environments of deposition: Continental, transitional and marine. The Benin Formation is the continental unit, comprising of massive continental sands with minor shale streaks and lignite, overlying the Agbada Formation, a sequence of interbedded sand/sandstone and shale occurring in almost equal proportion. The Agbada sandstone forms the reservoir unit, where there is a huge accumulation of hydrocarbon. The basal shale of the Agbada unit forms part of the source rock, whereas the Akata Formation (marine shale) underlying the Agbada is believed to be the major source rock. The delta has prograded through time for a distance of more than $300 \mathrm{~km}$ from the apex to the present delta nose (Doust and Omatsola, 1990). It is segmented into several morphological units, displaying a concentric arrangement often referred to as depobelts, which started with the oldest Northern Delta depobelt to the offshore depobelt and depicts the position of the paleocoastline at different times from Paleocene to Recent.

\section{Study Area}

The study area lies within the Greater Ughelli Depobelt of Oligocene age, in the onshore portion of the Niger Delta sedimentary basin (Fig. 2a and b).

Three wells studied in the field designated A, B and $\mathrm{C}$, cover an area of about $19 \mathrm{~km}^{2}$. The distance between Well A and B is $8 \mathrm{~km}$, whereas B and well C is also $8 \mathrm{~km}$. Well $\mathrm{A}$ and $\mathrm{C}$ are far apart by a distance of $15.2 \mathrm{~km}$. Several faults typical of the Niger Delta growth fault system occur in the field, which enhance hydrocarbon accumulation and entrapment. The area occurs between Latitude $5^{0} \mathrm{~N}$ and $5^{0} 25^{\prime} \mathrm{N}$ and Longitude $6^{\circ} 15^{\prime}$ and $6^{0} 30^{\prime} \mathrm{E}$ onshore location in the Greater Ughelli depobelt. 


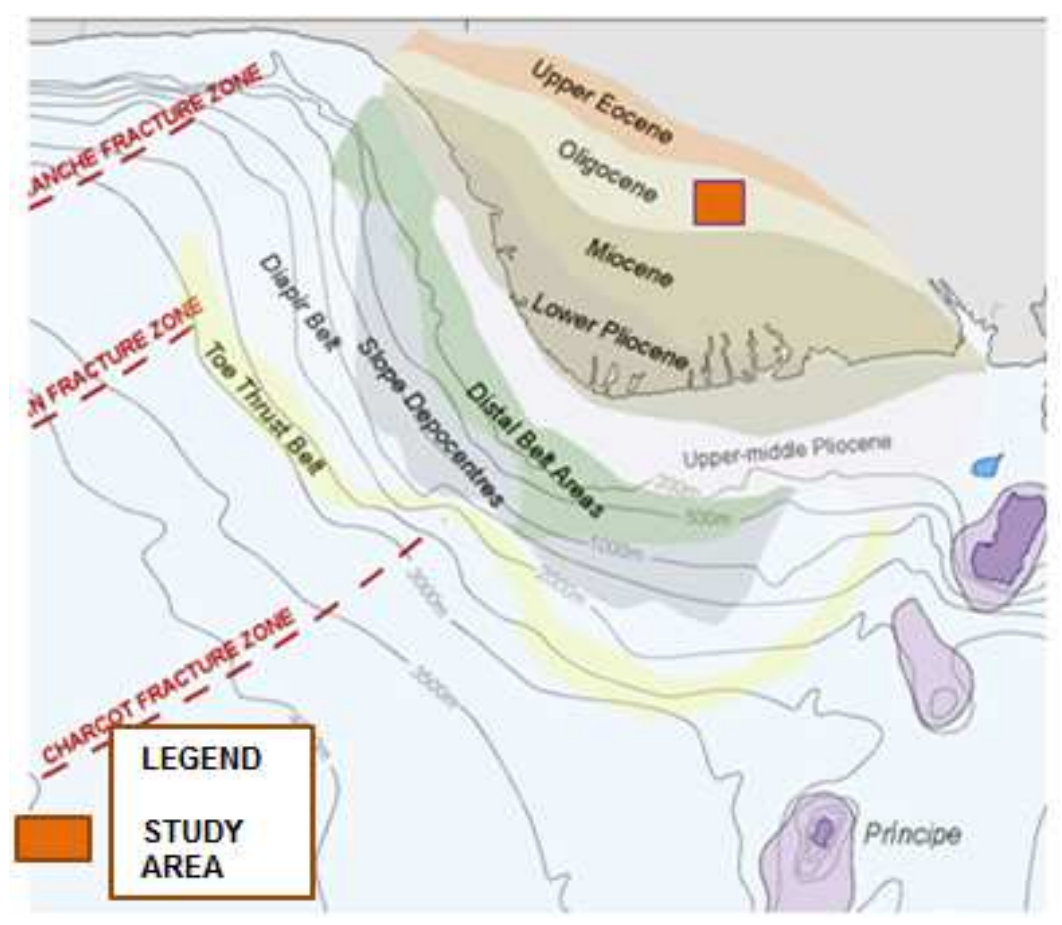

Fig. 1. Map of Niger Delta showing study location

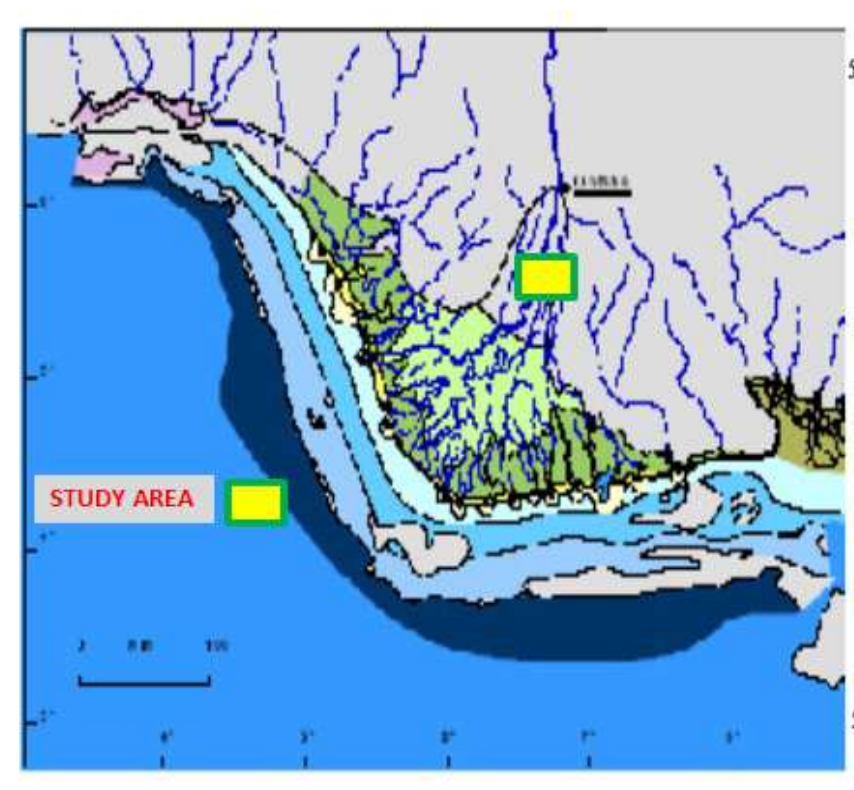

(a)

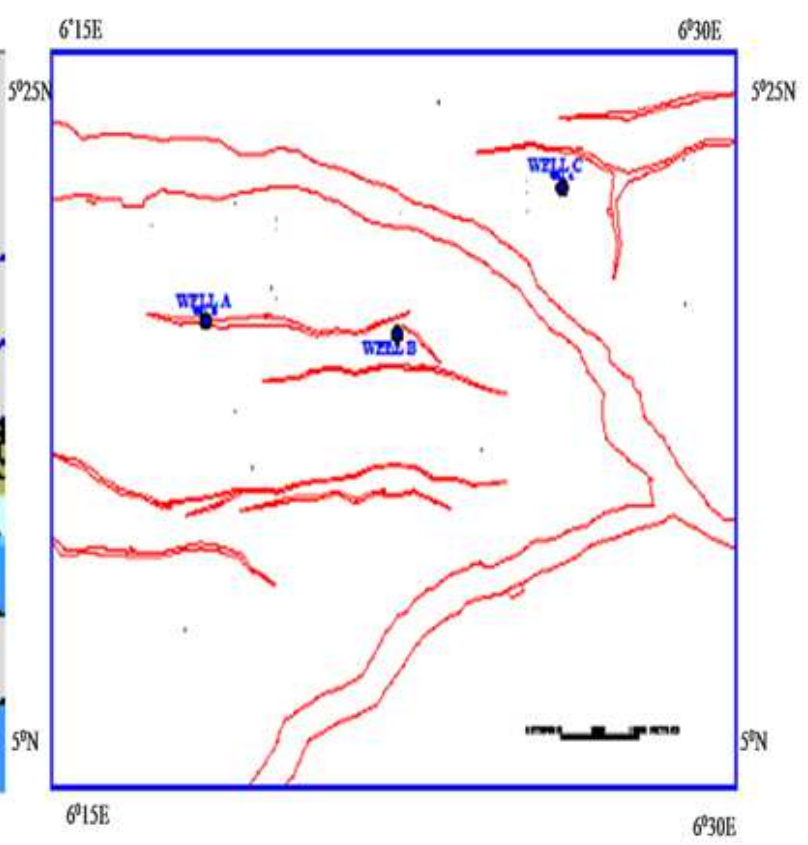

(b)

Fig. 2. (a) Map of study area (After Walker, 1992); (b) Well location map

\section{Materials and Methods}

The datasets for this study was provided by the Nigeria Agip Oil Company, Port Harcourt, for three wells labeled A, B and C. The data include a suit of well logs comprising of Gamma Ray, Spontaneous Potential, Resistivity, Sonic, Neutron and Density logs; and Core pictures for one well (well B).

Methods adopted in the interpretation of this data include: Well correlation-to establish the lateral 
continuity of key horizons; electrofacies analysis, involves using standard log motifs to infer the depositional environments of sand-bodies; core description for lithofacies identification and sedimentological interpretation; and finally petrophysical analysis of the D2 sand.

Litho-correlation was carried out on well log to delineate sand bodies and reservoir units (Fig. 4a and b). The top and base of key sand-bodies were correlated across the field base on the stacking trends of the reservoirs. Standard electrofacies by Selley (1985) was used to guide environmental interpretation from well log (Fig. 3).

Petrophysical parameters of the D2 sand were computed using Archie equations. Archie Equation 1 and 2:

$$
S_{w}^{n}=\frac{F \cdot R_{w}}{R_{t}}
$$

Where:

$S_{w}=$ Water saturation

$n=$ Saturation exponent, usually 2

\section{Porosity from Bulk Density}

$\operatorname{Porosity}\left(\varnothing_{D}\right)=\frac{\rho_{m a}-\rho_{b}}{\rho_{m a}-\rho_{f}}$

Where:

$\rho_{m a}$

$$
\begin{array}{ll}
\rho_{f} & =\text { fluid density } \\
\rho_{b} & =\text { bulk density } \\
\rho f\left(\text { fresh } \mathrm{H}_{2} \mathrm{O}\right)= & 1.0 \mathrm{~g} / \mathrm{cm}^{3}, \text { salt water }=1.146 \mathrm{~g} / \mathrm{cm}^{3}, \\
& \text { oil }(\mathrm{AP} 140)=0.85
\end{array}
$$

\section{Permeability from Timur Equation}

Timur (1968) studied 155 sandstone samples and presented his result statistically. The result shows the relationship between permeability, porosity and residual water saturation.

He stated that Equation 3:

$$
K=\frac{0.136 \varnothing^{4.4}}{\text { Swirr }^{2}}
$$

where, $K$ is the permeability; $\varnothing$ is the porosity and Swirr is the irreducible water saturation. Irreducible water saturation is the value of water saturation at which all of the contained water in the rock will be trapped by capillary pressure and/or by adsorption of water on the surface of rock grains (surface tension). At irreducible water saturation, all of the water within the reservoir will be immovable and hydrocarbon production will be water-free.

This relationship has been used extensively to estimate permeability. It is the best relationship used presently.

The cores were described to identify lithologies, sedimentary structures and used to reconstruct the depositional environments of the sand body.

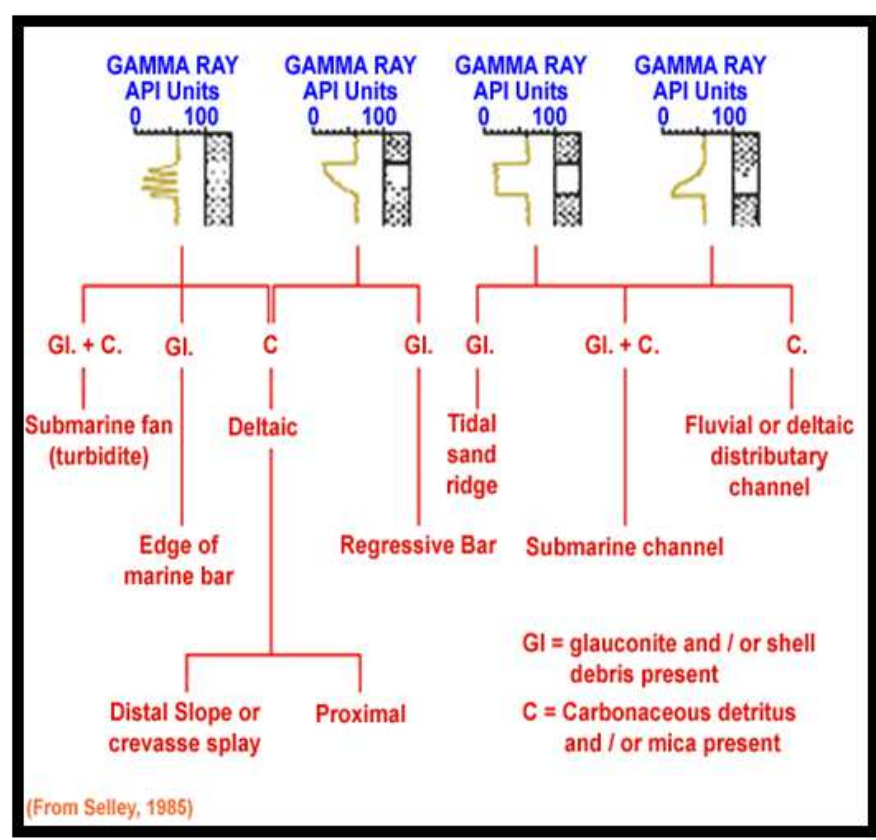

Fig. 3. Log motifs and depositional environments (Selley, 1985) 


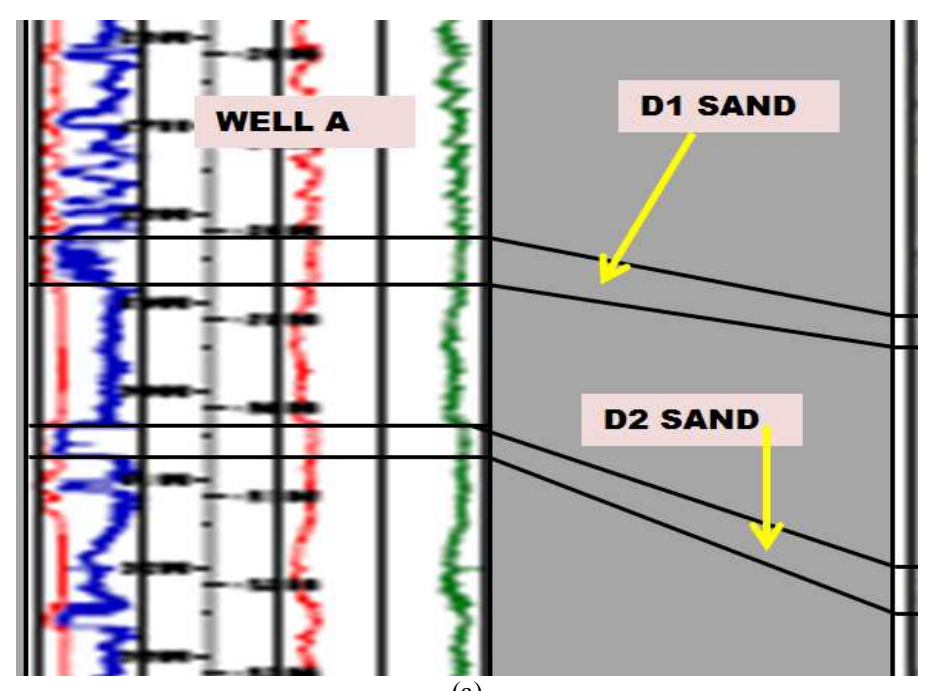

(a)

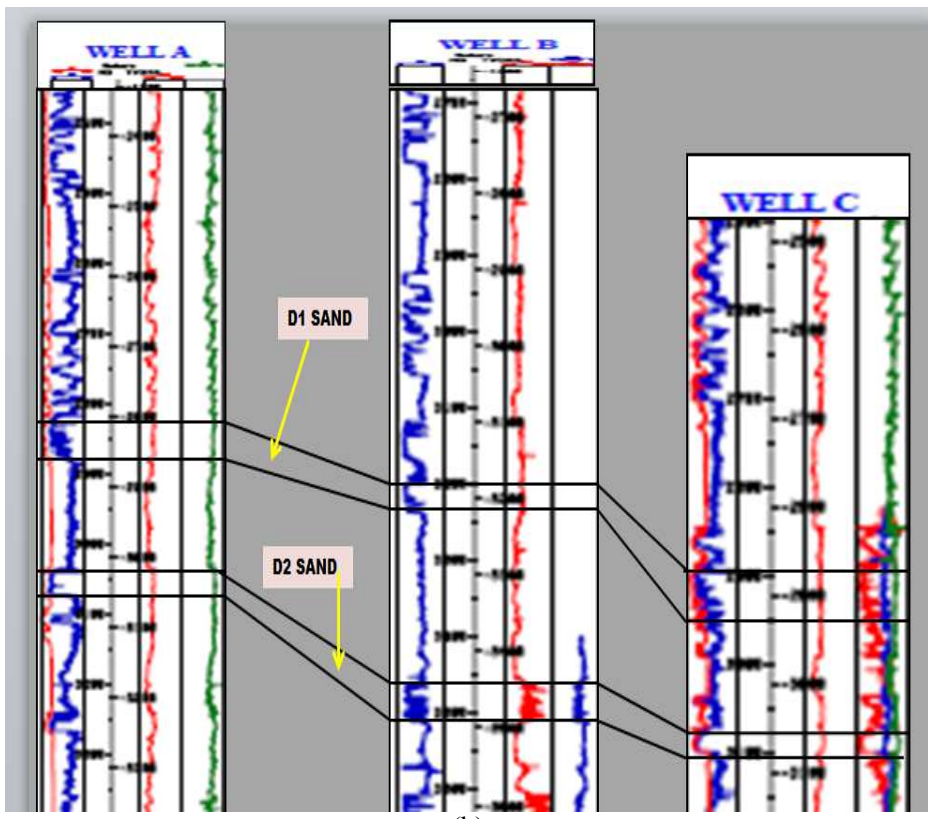

(b)

Fig. 4. (a and b) Litho-Correlation of D2 Sand across three wells in the field

\section{Results and Discussion}

Lithofacies and Depositional Environments from Cores

Four lithofacies were identified from the cored interval between 3444.5 to $3458.5 \mathrm{~m}$ depth. Each lithofacies were identified based on lithology characteristics, sedimentary structures and textural properties. The facies were grouped into associations for environmental interpretation.

\section{Facies A: Muddy Heterolithic Sandstone}

This facie shows a coarsening upward from intensely bioturbated sandy and muddy heterolithics to hummocky cross-stratified and rippled sandy heterolithics. Vertically it displays a progressive increase in sand/shale ratio (Fig. 5). Sands are wave-dominated with ripples and hummocky cross stratification.

\section{Interpretation}

The intensely bioturbated unit indicates reduced sedimentation rates on a low energy, or more slowly prograding shoreface. The hummocky cross stratification units reflect sedimentation under conditions of alternating storm and quiet water conditions between storm and fair weather base. The lower shoreface is characterized by poor reservoir quality at the heavily 
bioturbated units (0.79-6.0\%) (Table 1). It represents a thin-bedded shoreface reservoir.

\section{Facies B: Trough Cross-Stratified Sandstone}

This facies is characterized by shale-free sandstone successions. The basal unit is characterized by very well sorted, fine grained at the lower part to medium sandstone towards the top of the unit. This unit comprised of white to light grey, well-sorted, rarely bioturbated, trough cross-stratified sandstones (Fig. 6). It shows a general increase in grain size from the bottom of the section towards the top with a corresponding vertical increase in porosity from 6.0$10 \%$ (Table 1 ). The sedimentary structures and absence of shale deposits indicate deposition between fair weather wave base and beach.

\section{Interpretation}

The trough cross-stratification denotes the onshore migration of sandbars by nearshore currents in the surf zone, through fairweather periods (Howell and Flint, 2005). Rare bioturbation, medium-grained sandstones and very thin layers of dark organic deposits indicates a shallowing upward trend and high energy environment.

\section{Facies C: Sandy/Silty Mudstone}

This facies comprises of thinly laminated siltstone, very fine sandstone and predominantly mudstone. The basal part contains siltstone/very fine grained sandstone than the upper part as we see in the core (Fig. 7) towards $3450.5 \mathrm{~m}$ depth. Sedimentary structures include thin to medium beds of wavy heterolithics, interlaminated with thin mud drapes.

\section{Interpretation}

This unit is interpreted to be deposits by both suspension and bedload. Both heterolithic sandstone and the presence of mud drapes suggest a tidally influenced environment (tidal flat). Tidal environment is characterized by ebb-flood currents with suspension deposits during slack-water. The heterolithic sandstone facies is interpreted as formed during flood-ebb tidal currents with intervening slack-water suspension fallout in upper tidal flat and mudstone facies is formed in subtidal coastline setting. This portion occurs towards the top and is made up of largely shale and occasional poor quality very fine grained sandstone/siltstone (Fig. 6). Facies $C$ is a thinly laminated sands and shale of the tidal flat and tidal channel fills. It has limited biological diversity. They show lateral discontinuity and are highly variable in terms of reservoir quality (porosity ranges from 0-6.0\%) (Table 1). The Gamma Ray signature is highly serrated.

\section{Facies D: Crossbedded Sandstone}

This is a sandstone facies and occurred between 3444.9 and 3446.5 with thickness of $3.4 \mathrm{~m}$ (Fig. 8). It is made up of majorly clear to off white quartz grains and light brown to grey towards the base of the facies. Generally, the facies is poorly sorted, with trough cross bedding towards the basal part and low angle cross bedding at the top. Very fine grains occur towards the top with medium to coarse grains and pebbles at the base of this unit. The pebbles are subrounded to subangular in shape made up of quartz minerals forming lag at the base of the section. This facies displays a typical fining upward profile with high water saturation $(80 \%)$, porosity and permeability values range from $3-5.0 \%$ and $3.0-4.0 \mathrm{mD}$ (Table 1 ).

\section{Interpretation}

The fining upward trend is typical of unidirectional flow and is interpreted as sediments deposited within a channel. The crossbeds depict deposition by subaqueous dunes under strong, upper flow regime currents. During periods of strong lower flow regime, currents, migration of subaqueous dunes deposited the cross beds. The coarse to pebbly grained character of the sediments suggest a fluvial origin. Absence of visible shale and bioturbation shows deposition in a high energy environment.

\section{Lithofacies Association}

\section{Facies D (Channel Sand)}

Channel sandstone is characterized by unidirectional, cross-bedded, moderate to poorly sorted, fine-coarse grained sandstone. The coarse grained and poorly sorted sandstone reflects a fluvial dominated environment in which sand deposition was as a result of the migration of sinuous to straight crested dunes under high energy fluvial currents. The Gamma Ray has a blocky profile with weak fining upward (Fig. 4a).

\section{Interpretation}

This can be interpreted as tidally influenced fluvial dominated channel formed in marginal marine incised valley settings (Fig. 8). It is characterized by good to very good reservoir quality. Porosity and permeability of this type of reservoir range from $21-27.2 \%$ and $173 \mathrm{mD}$.

\section{Facies C (Tidal Flat)}

This is made up of largely shale and occasional poor quality very fine grained sandstone/siltstone (Fig. 7). It is a thinly laminated sands and shale of the tidal flat and tidal channel fills. It has limited biological diversity. They show lateral discontinuity and are highly variable in terms of reservoir quality (porosity ranges from 0$4.0 \%$ ) (Table 1). The Gamma Ray signature is very high. 


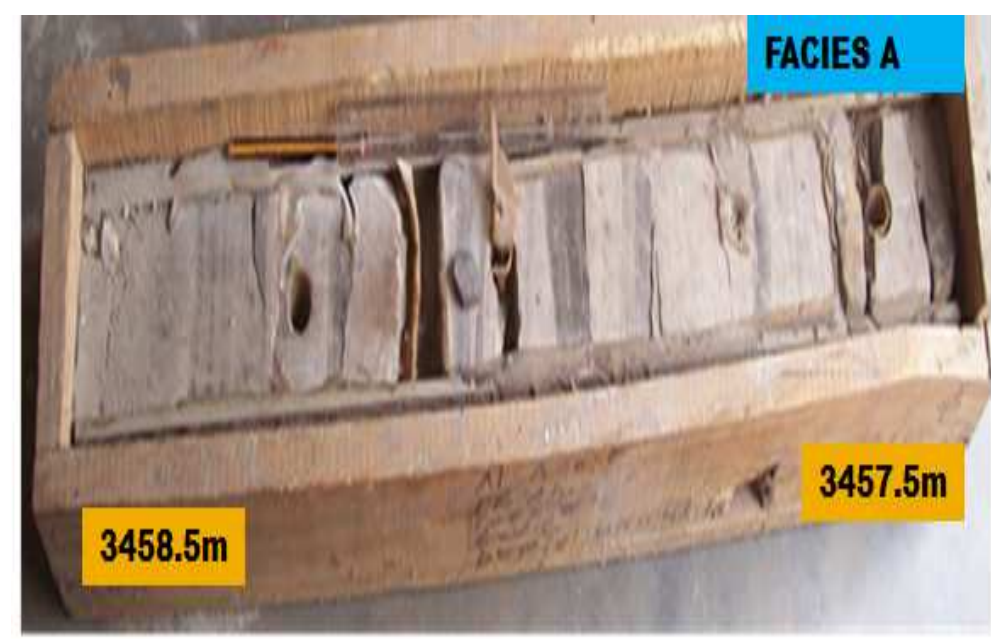

Fig. 5. Facies A, showing muddy heterolithic sandstone of lower shoreface

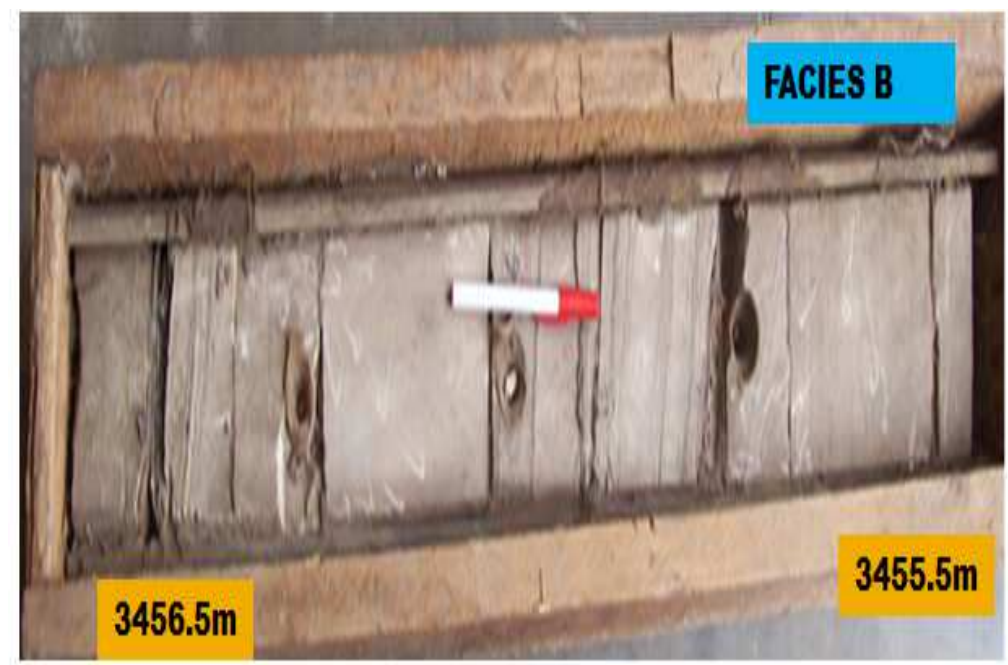

Fig. 6. Facies B, showing trough cross-stratified sandstone of the upper Shoreface

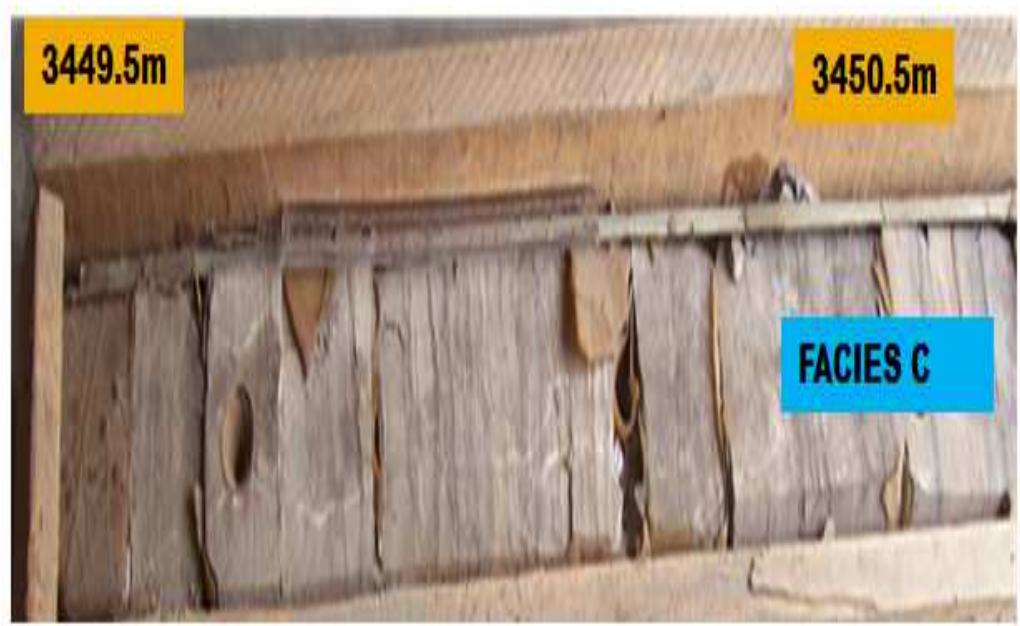

Fig. 7. Sandy-silty heterolithic mudstone 


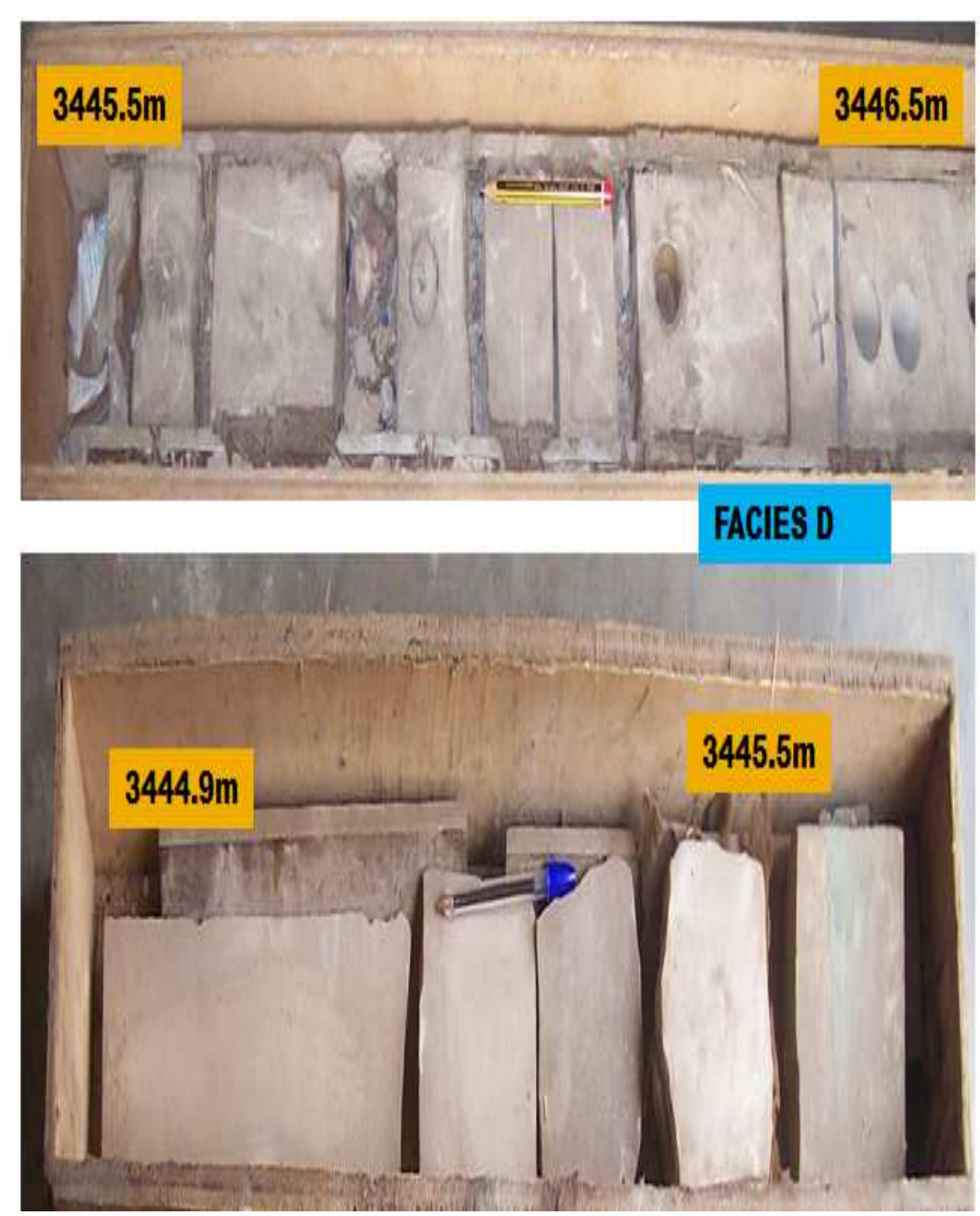

Fig. 8. Cross-bedded fine-coarse grained sandstone facies. Clay clasts occurred between 3445.5 and $3446.5 \mathrm{~m}$. Coarse grains and granules occur towards the base of this section

Table 1. Petrophysical table for D2 Reservoir in Well B

\begin{tabular}{llll}
\hline DEPTH $(\mathrm{m})$ & $\Phi_{\text {dcorr }}$ & Sw & $\mathrm{K}(\mathrm{mD})$ \\
\hline 3443 & 3.295097 & 0.829552 & 1.821576 \\
3444 & 5.317751 & 0.615828 & 4.533540 \\
3445 & 5.317751 & 0.615828 & 4.533540 \\
3446 & 10.32698 & 0.301714 & 8.804053 \\
3447 & 10.32698 & 0.301714 & 8.804053 \\
3448 & 4.836095 & 0.498063 & 4.122913 \\
3449 & 4.836095 & 0.498063 & 4.122913 \\
3450 & 0.790787 & 0.791465 & 0.253972 \\
3451 & 0.790787 & 0.801465 & 0.253972 \\
3452 & 6.281671 & 0.446899 & 2.017445 \\
3453 & 6.281671 & 0.446899 & 2.017445 \\
3454 & 6.281671 & 0.446899 & 2.017445 \\
3455 & 6.281671 & 0.446899 & 2.017445 \\
3456 & 6.089008 & 0.462118 & 1.955569 \\
3457 & 6.089008 & 0.462118 & 1.955569 \\
3458 & 8.111662 & 0.445424 & 4.484239 \\
3459 & 8.111662 & 0.445424 & 4.484239 \\
3490 & 6.089008 & 0.623224 & 1.955569 \\
\hline
\end{tabular}

\section{Facies B (Upper Shoreface)}

This facies is characterized by shale-free sandstone successions. They usually form facies that are continuous and laterally extensive within the marginal marine environment. The gamma ray trend showing a coarsening upward sequence is an indication of progradational parasequence. The basal unit is characterized by very well sorted, fine grained sand whereas medium grained occur towards the top. In vertical facies relationship, it is overlain by the tidally influenced environment made up of largely shale and occasional poor quality very fine grained sandstone/siltstone (Fig. 9). The sedimentary structures and absence of shale deposits indicate deposition between fair weather wave base and beach.

\section{Facies A (Lower Shoreface)}

This facie shows a coarsening upward from intensely bioturbated sandy and muddy heterolithics to hummocky 
cross-stratified and rippled sandy heterolithics. Vertically it displays a progressive increase in sand/shale ratio. Sands are wave-dominated with ripples and hummocky cross stratification.

\section{Interpretation}

The intensely bioturbated unit indicates reduced sedimentation rates on a low energy, or more slowly prograding shoreface. The hummocky cross stratification units reflect sedimentation under conditions of alternating storm and quiet water conditions between storm and fair weather base. The lower shoreface is characterized by poor reservoir quality at the heavily bioturbated units (4.0-6.0\%). It represents a thin-bedded shoreface reservoir.

\section{Depositional System of the D2 Reservoir}

The lithologies of the study area are broadly classified into sand and shale as revealed by both well $\log$ and core samples. The Gamma Ray log has a shale reference line of $85^{\circ}$ API, chosen from the usual potential of $0-150^{\circ} \mathrm{API}$. Increasing gamma ray values to the right of the reference line indicates increasing shale/clay, whereas decreasing gamma ray to the left of the reference line indicates increasing sand percentage. The procedure adopted involves recognizing patterns that show changing water depths and sediment distribution within a depositional package. A coarsening upward or fining upward unit within a forestepping or backstepping successions (Table 2) of the log defines stacking patterns of genetic units. This aided well correlation and delineation of sand bodies of interest.

The D2 sand shows a coarsening upward progradational stacking. The reservoir cuts across the three wells with variable thicknesses $(55,65$ and $95 \mathrm{~m})$ (Fig. 4a and b). Top of this reservoir occurs at 3610,3455 and $3245 \mathrm{~m}$ in the three wells. It has an average porosity and permeability of $0.7-10.3 \%$ and $0.2-8.8 \mathrm{mD}$, with average water saturation of $80 \%$ in well $\mathrm{B}$. This reservoir has a tendency of producing more water than hydrocarbon in well B. Changes in petrophysical characteristics of the reservoirs is as a result of change in facies. Lateral rock-type variations due to depositional facies changes can anomalously affect apparent oil-water contacts (Davis, 1992).

Three depositional environments common to the deltaic system include; delta plain, delta front and prodelta. These are represented by the three major formations of the Niger Delta (Benin, Agbada and Akata). The Benin Formation is encountered between the intervals of 1200 to $2420 \mathrm{~m}$ in well B (Table 2). This is the continental sand facies with minor shale intercalations. Interpretations based on $\log$ motif patterns, sedimentary cycles, etc, show that the payzones (reservoir sand-bodies) contain one or more of the following genetic types: Deltaic distributary channels, mouth bars, barrier bars, channel point bars (meandering channels), overbanks, marsh and fluvial deposits. Among the three sand-bodies correlated on well log (D0, D1 and D2), D2 is used as analogue to infer the sedimentology and depositional setting of other sandbodies that have similar genetic attributes with the D2 unit. The D2 sand unit occurs within sequence 2 in the study area (Momta and Odigi, 2014) and is traceable in the three wells. Based on gamma ray log motifs and the core sample description, sand-bodies in the study area represent deposition in a foreshore/shoreface to shallow marine shelf environments affected by the actions of both fluvial and marine processes.

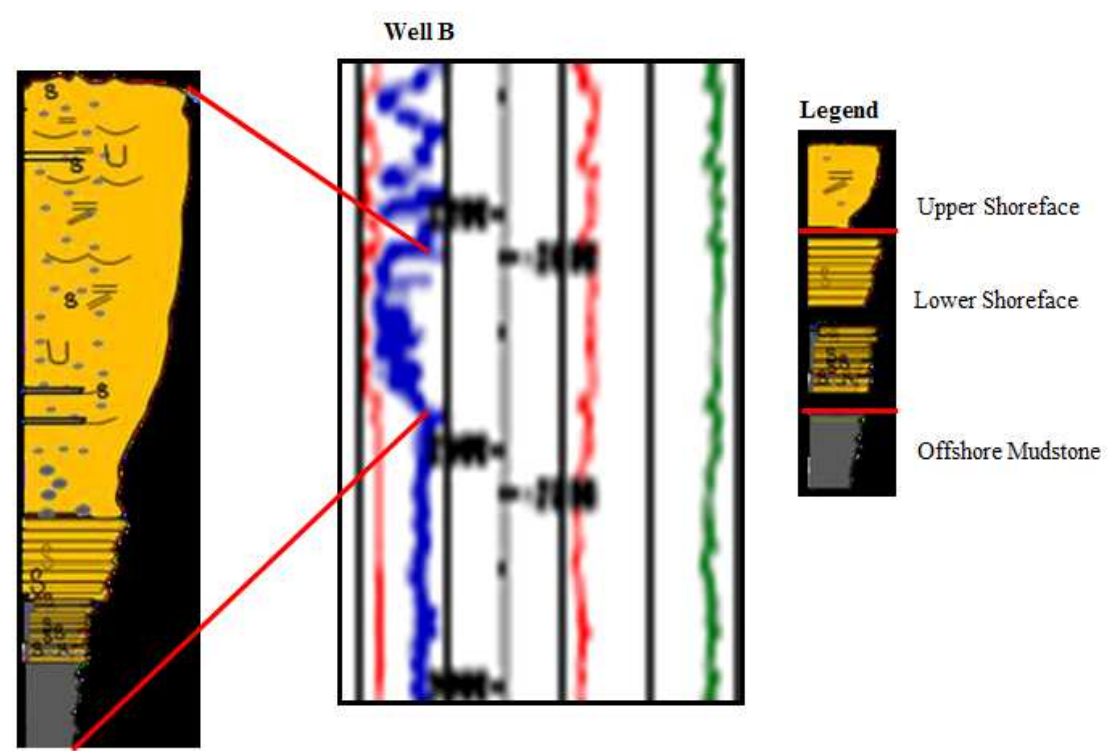

Fig. 9. Facies Model Showing the Various subenvironments within the D2 Sand 
Table 2. Depositional environments from well log (Well B)

\begin{tabular}{|c|c|c|c|}
\hline Depth (m) & Log shape & Reservoir & Environments \\
\hline $1200-2420$ & $\begin{array}{l}\text { No definite shape but gamma ray } \\
\text { shows sand with minor shale intercalations. }\end{array}$ & D0 & $\begin{array}{l}\text { Delta plain } \\
\text { (channel sand, point bars, levee, overbanks (Benin Formation). }\end{array}$ \\
\hline $2625-2775$ & Funnel shape (coarsening upward) & D1 & Interdistributary beach, barrier bar, shoreface \\
\hline $3445-3520$ & Funnel (serrated) & D2 & Shoreface, Interdistributary beach, barrier bar/foot, mouth bar \\
\hline
\end{tabular}

\section{Distributary Channel}

Distributary channel consists of stacked thick massive sandstone, medium to coarse-grained and sometimes gravelly. It usually forms good quality reservoirs. It occurs within the delta plain environment and is the site for the deposition of most of the coarse grained sediments carried to the delta. They show a tendency to migrate laterally to form point bar sands which show cross beddings oriented downstream or generally towards the basin, except in tide dominated situations where bidirectional cross-stratification is common (Walker, 1992). These sands also display ripple cross-stratifications and scour and fill structures and they may include thin discontinuous clay lenses. Distributary channel is recognized on gamma ray log with their blocky or cylinder shape.

\section{Interdistributary Bay}

This environment is less complex than the distributary channel. They comprise the bulk of the area on the delta plain and represent the lowest-velocity environment on the upper delta surface except for abandoned channels. Interdistributary bays are shallow and accumulate sediment slowly. Most of the sediment is silt and clay with scattered shell debris from shallow water benthic organisms. Local, thin sand or shale lenses may be present as a result of reworking by storm conditions parallel laminations and burrow mottling is widespread (Walker, 1992). They are recognized on the $\log$ by the funnel shape of gamma ray showing a coarsening upward sequence just like the D2 sand.

\section{Estuary Mouth Bar}

The mouth bar deposit shows a distinctive upward coarsening sequence of medium-grained sandstones. It displays compound cross-stratification with leesidedescending ripple sets. Cross-bedding is dominantly unidirectional and is accompanied by flaser bedding and double mud drapes. It contains sedimentary features resembling those formed at the mouth of distributaries in various deltaic settings, particularly where there is strong tidal current flow. The gamma ray expression of this unit shows funnel shape motif (coarsening upward). The reservoir quality is in part, a function of the moderately well sorted nature of the sandstone.

\section{Conclusion}

The sedimentology and depositional environments of D2 sand in part of the Greater Ughelli depobelt have been studied using well logs from three wells and cored section of well B. Well $\log$ and core information show that the D2 sand was deposited within the deltaic front environment. This environment is affected by various marine energy fluxes which include wave action, longshore currents and tidal effects. These processes are responsible for distribution and deposition of sediments within the shoreface (upper and lower shoreface), barrier complexes, tidal flats and channel, interdistributary bay and mouth bars. The D2 sand shows typically an environment ranging from offshore mudstone to shoreface subenvironments. Tidal flat facies separated the upper shoreface from a channel at the top of the sequence. Coarsening upward trend of gamma ray log confirms the progradational depositional profile of the sand unit. Four facies associations indicating subenvironments of D2 sand include; Lower Shoreface, Upper Shoreface, Tidal Flat and Channel sand respectively. The lithofacies types making up the sedimentary unit include; muddy heterolithic sandstone, trough cross stratified sandstone, sandy/silty mudstone and crossbedded sandstones. Petrophysical properties vary among the different facies from 0.79 to $10.32 \%, 0.25$ to $8.8 \mathrm{mD}$ and 0.3 to 0.8 for porosity, permeability and water saturation. This variation in petrophysical properties shows that facies distribution has a significant control on reservoir properties. Relatively fair to good reservoir quality occurred within the channel and upper shoreface and poor quality within the lower shoreface and tidal flat. Clay and shale drapes are important flow barriers and poroperm inhibitors within these subenvironments.

This study has demonstrated that the D2 reservoir was deposited within the deltaic to shoreface shallow marine environments, where facies change laterally seaward from coarse grained within the upper shoreface to heterolithics and offshore mudstone towards the shelf. Facies types, architecture and geometry are functions of sedimentology and deposition setting of sediments and required detailed study to understand fluid storage and flow capacities. 


\section{Acknowledgement}

I appreciate the Department of Petroleum Resources, Port Harcourt, for authorizing the release of this data by the Nigerian Agip Oil Company (NAOC), Port Harcourt.

\section{Funding Information}

This research was supported financially by Engr. LeBari Nania of Nigeria Agip Oil Company, Port Harcourt, Nigeria.

\section{Author's Contributions}

All the authors contributed towards the analysis, interpretation and the writing of this manuscript.

\section{Ethics}

This article is original and contains unpublished material. The corresponding author confirms that all of the other authors have read and approved the manuscript and no ethical issues involved.

\section{References}

Amajor, L.C. and D.W. Agbaire, 1989. Depositional history of the reservoir sandstones, akpor and apara oilfields, eastern Niger Delta, Nigeria. J. Petroleum Geol., 12: 453-464. DOI: $10.1111 /$ j.1747-5457.1989.tb00243.x

Arochukwu, E., 2014. Assessing the impact of reservoir architecture on secondary recovery: A case study of "century" field, Niger Delta. Proceedings of the NAPE Monthly Technical Meeting, (MTM' 14), Port Harcourt, Nigeria.

Bruso, J.M., S.L. Getz and R.L. Wallace, 2004. Gulf of guinea geology. Oil Gas J. Special Rep.

Davis, R.A., 1992. Depositional Systems: An Introduction to Sedimentology and Stratigraphy. 1st Edn., Prentice Hall, Englewood Cliffs, ISBN-10: 013202912X, pp: 604.

Doust, H. and E. Omatsola, 1990. divergent and passive basin of the Niger Delta. AAPG Memoir, 48: 599-604.

Ejedawe, J.E., 1981. Patterns of incidence of oil reserves in Niger Delta basin. Am. Assoc. Petroleum Geol. Bull., 65: 1574-1585. DOI: 10.1306/03B5962016D1-11D7-8645000102C1865D

Fitch, P.J.R., M.D. Jackson, G.J. Hampson and C.M. John, 2014. Interaction of stratigraphic and sedimentological heterogeneities with flow in carbonate ramp reservoirs: Impact of fluid properties and production strategy. Petroleum Geosci., 20: 7-26. DOI: 10.1144/petgeo2013-014
Howell, J.A. and S.S. Flint, 2005. Tectonic Setting, Stratigraphy and Sedimentology of the Book Cliffs, the Parasequence of the Book Cliffs Succession, Sequences and Systems Tracts in the Book Cliffs, Sequence Stratigraphical Evolution of the Book Cliffs Succession. In: The Sedimentary Record of Sea-Level Change, the Open University, Coe, A.L. (Ed.), Cambridge University Press, pp: 135-208.

Keele, D. and J. Evans, 2008. Analysis of reservoir properties of faulted and fractured eolian thrust-belt reservoirs. Utah Geological Survey.

Magbagbeoloa, O. and B.J. Willis, 2007. Sequence stratigraphy and syndepositional deformation of the Agbada Formation, Robertkiri field, Niger Delta, Nigeria. Am. Assoc. Petroleum Geol. Bull., 91: 945-958. DOI: 10.1306/02050705150

Momta, P.S and M.I. Odigi, 2014. Sequence stratigraphic framework and depositional architecture of MP field, shallow offshore, Niger Delta, Nigeria. Proceedings of the NAPE Annual International Conference and Exhibitions, Nov. 9-13, Lagos, Nigeria.

Reijers, T.J.A., 2011. Stratigraphy and sedimentology of the Niger Delta. Geologos, 17: 133-162. DOI: $10.2478 / \mathrm{v} 10118-011-0008-3$

Selley, R.C., 1985. Elements of Petroleum Geology. 1st Edn., W.H. Freeman and Company, New York, pp: 448.

Slatt, R.M., 2006. Stratigraphic Reservoir Characterization for Petroleum Geologists, Geophysicists and Engineers. 1st Edn., Elsevier Science, pp: 492.

Snedden, J.W. and K.M. Bergman, 1999. Isolated Shallow Marine Sand Bodies: Deposits for all Interpretations. In: Isolated Shallow Marine Sand Bodies: Sequence Stratigraphic $\backslash$ Analysis and Sedimentologic Interpretation, Bergman, K.M. and J.W. Snedden (Eds.), SEPM Special Publication, pp: 1-11.

Timur, A., 1968. An investigation of permeability, porosity and residual saturation relationship for sandstone reservoirs. Log Analyst, 9: 8-8.

Walker, R.G., 1992. Facies Models and Modern Straigraphic Concepts. In: Facies Models: Response to Sea Level Change, Walker, R.G. and N.P. James (Eds.), Geological Association of Canada, St., John's, Nfld, ISBN-10: 0919216498, p: 1-14.

Whiteman, A., 1982. Niger Delta, Its Petroleum Geology, Resources and Potential. 1st Edn., Graham and Trotman Ltd, London, pp: 176. 